Stevo Jokić ${ }^{1}$

Aleksandar Sandro Cvetković ${ }^{2}$

Saša Adamovićc ${ }^{3}$

Nenad Ristić ${ }^{4}$

Petar Spalevićs

Sinergija University, Faculty of computing and informatics, Bijeljina, BiH
SCIENTIFIC REVIEW ARTICLE doi:10.5937/ekonomika1903065J

Received: Jul 29. 2019.

Accepted: September, 03. 2019.

\title{
COMPARATIVE ANALYSIS OF CRYPTOCURRENCY WALLETS VS TRADITIONAL WALLETS
}

\begin{abstract}
In this paper, we deal with comparative analysis of cryptocurrency wallets and traditional wallets. In addition to security analysis, we will observe the most important elements that should ensure a high level of social acceptability. In that regard, we will make a brief overview of the existing mechanisms for disposing a funds expressed in traditional currencies as well as for crypto currencies. Under the traditional safe keeping mechanisms and the disposal of cash, we will consider systems based on payment cards, payment by cash and payments over the internet. The use of digital wallets is reflected in various characteristics. The convenience of using the ability to execute a mobile phone transaction in matter of seconds. Efficiency is reflected in the speed of transaction execution. This paper describes the current state of digital wallets on the market, the choices of a better solution for purchasing and using digital wallets, security of digital wallets and future trends in their development.
\end{abstract}

Key words: Digital wallet; Cryptocurrency wallet; Cryptocurrencies; Security; Transactions

JEL classification:E4, E5, E6

\section{КОМПАРАТИВНА АНАЛИЗА КРИПТОВАЛУТНИХ И ТРАДИЦИОНАЛНИХ НОВЧАНИКА}

\begin{abstract}
Апстракт
У овом раду бавимо се компаративном анализом криптовалутних и традициналних новчаника. Поред анализе безбедности, ми ћемо посматрати најважније елементе који би требали осигурати висок ниво друштвене прихватьивости. У том смислу, ћемо направити кратак преглед постојећих механизама за смештаье средстава изражених у традичиналним валутама као и криптовалутама.Према традиционалним механизмима сигурног чувања и располагања готовином раз-
\end{abstract}

\footnotetext{
${ }^{1}$ sjokic@sinergija.edu.ba

2 ascvetkovic@sinergija.edu.ba

33sadamovic@sinergija.edu.ba

${ }^{4}$ nristic@sinergija.edu.ba

${ }^{5}$ pspalevic@sinergija.edu.ba
} 
мотрићемо системе засноване на платним картрицама, плаћағу готовином и плаћағима преко интернета. Коришћење дигиталних новчаника се огледа у различитим карактеристикама. Погодност коришћена је извриавање трансакиија у секунди путем мобилног телефона. Ефиксаност се одражава брзином извриавања трансакиије. Овај рад описује тренутно стање дигиталних новчаника на тржишту, избор бољег решења за куповину и коришћење дигиталних новчаника, безбедност дигиталних новчаника и будуће трендове у њиховом развоју.

Кључне речи: Дигитални новчаник; Криптовалутни новчаник; Криптовалуте; Безбедност; Трансакиије

\section{Introduction}

Cash payment has been going on for a long time and it's hard to get it out of everyday use, especially for the elderly. Moreover, some smaller businesses avoid paying taxes and therefore payment is only in cash.

Cash advantages:

- Tangible money in the hands of client

- There is no payment of fees after the completed transaction

- There is no need for a bookkeeper

Cash disadvantages:

- Tangible money can lead a person to quickly spend it

- It can be stolen

Payment with credit cards is very popular today in addition to cash payments. Visa and MasterCard are dominating the market. In relation to cash payment, this method of payment comes with the price. Every transaction executed through the card implies taking a commission. (NXGEN, n.d.)

Credit card advantages:

- Purchasing more expensive items by paying the same monthly instalments

- Customer protection in the sense that if it does not receive a paid product, there is a possibility to refund money

Credit card disadvantages:

- Delaying a single instalment payment may cause additional costs

- Paying extra penalties if the limit is exceeded

- By choosing the right card, the client has the ability to control costs

(Credit card cons and pros, n.d.)

Nowadays, information technology has grown in all spheres of business and thus has brought a more modern way of paying services over the internet.

Advantages:

- The virtual transfer of money is much faster than the traditional way of paying.

- The possibility of paying anywhere in the world

- $\quad$ Reduced risk of losing money

Disadvantages: 
- Internet connection is required

- All information about the transactions, the sender and the recipient is stored in the database which represents the lack of anonymity for clients

- A limited number of transactions and a limited amount of money that can be spent. (Advantages and disadvantages of electronic payment systems, n.d.)

A digital wallet for cryptocurrencies is a software program that holds public and private keys and successfully works on different blockchains which allow users to exchange currencies between each other and to keep track of the balance of their currency. A digital wallet can store, send and receive different currencies. Cryptocurrencies are not stored as physical (fiat) money within the wallet. Every transaction is recorded and stored in the blockchain. Sending a Bitcoin or some other currency to a user would mean sending out your own public key. If the user should receive the payment his private key must be in accordance with the sender's public key. There is no real exchange of coins. The transaction was concluded with a record in the blockchain and a change in user digital wallet. (Cryptocurrency Wallet Guide: A Step-By-Step Tutorial, 2018)

These keys are part of the science called cryptography. There are two basic models for security symmetric and asymmetric model. The symmetric model usually comes with secret key and asymmetric model comes with public and private key. The focus will be on asymmetric model, because this model is commonly used in completing cryptocurrency transactions. Asymmetric encryption is an encryption model that uses different encryption and decryption algorithms as well as two keys that are linked with each other (private and public key). The sender should have a copy of the public key of the recipient but in that case it must be considered that the attacker has the same copy. In this case, the sender encrypt the message with the proper algorithm for encryption, and the recipient has the ability to decrypt the message with his private key. So the purpose of this asymmetric model is that the attacker cannot decrypt a message which is encrypted by the public key. (Veinović \& Adamović, 2013)

Cryptocurrency wallets can be divided into two major categories and they are: cold wallets and hot wallets. The difference between two of them is that for hot wallets an internet connection is necessary and for cold wallets is not. Hot wallet users usually use them in order to buy something on the internet and hold a small amount of money for that purpose, while cold wallet is just like vault in the bank to store different kind of digital values. The best thing is to have both wallets mainly for security reasons.

Hot and cold wallets can be divided into several categories: online wallets, hardware wallets, mobile wallets, paper wallets and desktop wallets. Online, mobile, desktop and multisignature wallets belong to a hot wallet category and hardware, paper belongs to a cold wallet category. Depending on the choice of digital wallet, each has its own level of security to ensure to protect the private key.

Multisignature wallets: In order to access funds after completing a transaction through multisignature wallet, two or three private keys will be needed depending on the level of security. This practice is good for companies that give responsibility to a different employee which means they all need to give their private key to gain access to funds. Example of multisignature wallet is BitGo where user store one key, second key is stored by a person of trust and the third key is kept by company itself. (The difference between hot and cold wallets in the digital currency world, n.d.) 
Online wallets: Access to this type of wallets can be via web browser. These wallets are vulnerable so it is not recommended to store a larger amount of crypto token to this wallet.

Advantages:

- Transactions are completed in short amount of time

- Recommended to store a small amount of cryptocurrency

- Some of these digital wallets are suitable for storing several different cryptocurrencies and making transfer between them

- $\quad$ Possibility of using TOR network for more privacy

Disadvantages:

- The full control of digital wallet is in hand of third party or central authority

- It is recommended to use a personal computer when using digital wallet and is necessary to have security software installed

- Lack of knowledge in information technologies leads users to the risk of various online frauds

Mobile wallets: When using mobile wallets users have access at every place with internet connection.

Advantages:

- More useful and easier to use than other types of cryptocurrency wallets

- $\quad$ Possibility of using the TOR network for more privacy

- A great feature is using QR code for scanning

Disadvantages:

- Mobile phones are insecure devices. A user can lose his crypto tokens if the phone becomes compromised.

- $\quad$ They are susceptible to malware, key logger and viruses

Desktop wallets: are considered safer than the previous two types of wallets.

Advantages:

- Very easy use

- Private keys are stored on the user's computer

Disadvantages:

- If a computer has a connection to the internet it becomes vulnerable and requires higher security

- Regular backup is necessary because in some point system may break down and all data could be lost

Higher level of security for desktop wallets can be obtained by possessing an older laptop with clean operating system. This kind of laptops can implement a cold storage method. The concept of cold storage in cryptocurrency is for users who want to store their digital assets for a very long time. There are several types of laptops that can be used as a cold storage for cryptocurrencies. That laptop's only purpose should be for storing digital assets or a lightweight crypto mining rig. It should have a safe operating system such as MacOS, Ubuntu or ChromeOS (Chromebook). The first convenient crypto laptop is Xiaomi Air with a fingerprint sensor as an extra layer of security. Price range for this 
laptop starts at $900 \$$ and represents good investment. Second best investment in crypto laptop would be buying Huawei MateBookX13 with starting price range at $800 \$$. At this moment Huawei Company is making these laptops only with Windows operating system. The third and the cheapest laptop is Asus Chromebook Flip with the highest price range of $500 \$$. This is the best-selling laptop with a ChromeOS which is very secure. It has an ability to work with other USB cryptocurrency wallets.

Hardware wallets: are one of the most secure wallets. They are usually in the form of a USB device with software in it. Some of them have a screen which means the user doesn't need a computer to complete a transaction. This type of wallet offers more control over the user's cryptocurrency and represents a proper solution to store digital assets for a long time.

Advantages:

- The most secure USB wallets are with the screen on it

- Safer than all the other types of wallets

Disadvantages:

- Very difficult to buy

- It's not recommended for beginners

Paper wallets: These are the safest wallets that exist. They belong to cold storage wallets. As the name says, paper wallet is a piece of printed paper with public and private keys. The paper has a QR code which represents the user key and can be used for any transactions. The only concern of the user should be to keep that piece of paper and that is the main reason why this type of wallet is concerned to be the safest.

Advantages:

- Stored in the user pocket or physical wallet without any connection to the computer

Disadvantages:

- It takes more time to complete the transaction

Multi-currency wallets can be a good investment for users who want to trade with various currencies. Bitcoin was the first currency, but there are hundreds of different currencies in the market and every one of them has a different infrastructure. (Cryptocurrency wallets types, n.d.)

\section{The best digital wallets on the market}

Before choosing a cryptocurrency wallet important thing to know is that the digital currency is in some countries banned or restricted and some countries allows its use and trade. It is possible to choose a wrong wallet for certain digital currency and to lose the money. Recommended thing for users is to spend some time in order to explore how different types of cryptocurrency wallets work. A few different popular wallets are: Ledger Nano S (hardware wallet), Ledger Blue (hardware wallet), Coinpayments (online wallet), Exodus (online wallet), Jaxx (mobile wallet). 
Ledger Nano $\mathbf{S}$ is a hardware digital USB wallet made for cryptocurrencies. Although hardware wallets are more expensive than the other type of wallets it is a cost-effective investment with a lot of different features. Special attention is devoted to a security and the backup of the private key. It has a small screen in the front of the device so it can be managed without any difficulties. Various functions are available such as exchanging digital currencies, transferring money from account to account etc. Figure 1. shows Ledger Nano S digital wallet.

\section{Figure 1: Ledger Nano $S$}

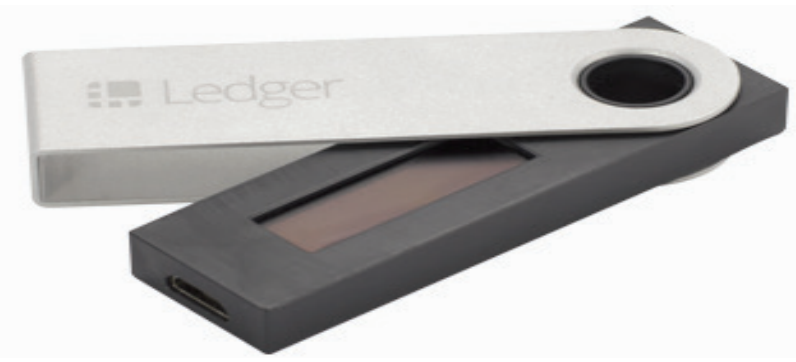

Source: https://www.ledgerwallet.com/products/ledger-nano-s

Ledger Nano $\mathrm{S}$ has two sizes. $98 \mathrm{~mm}$ is the bigger device and the smaller device is $60 \mathrm{~mm}$. The main features of these hardware wallets are:

- Multi-currency wallet - This wallet has an ability to store many different popular cryptocurrencies in the same wallet

- Small screen - User can watch on-going transactions and use the button to verify them.

- User-friendly - No matter the device is small, user can still operate comfortably

- $\quad$ Safety measure - For this purpose there is plenty options for security as well as option to lock the wallet using a pin code

- Backup and recovery - In case of losing cryptocurrency money restoration process is very fast

Ledger Blue is also hardware wallet made by the same company. It is much more superior than Ledger Nano S with lots of new options. Because of these features this wallet is among the most expensive wallets on the market. Figure 2. shows Ledger Blue digital wallet.

\section{Figure 2:Ledger blue}

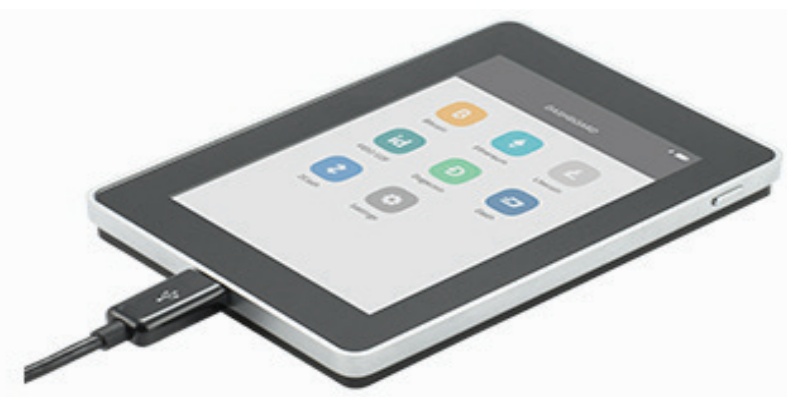

Source: https://www.ledgerwallet.com/products/ledger-blue 
The most important security features are shown below:

- Security - Ledger blue wallet is based on dual chip technology and has an integrated firmware for protection of digital currencies

- Resistant to malicious software - this wallet cannot be hacked which means that it is $100 \%$ resistant to malicious software

- $\quad$ Pin code - user can set 4 to 6 digits code to limit outside access

Coinpayments are online digital wallet. The wallet has a high level of popularity because it can store more then 300 different currencies. The only fee they charge is when user completes the transaction through their wallet. For that reason wallet is accepted in many online stores, so it is possible to use this wallet for online purchase. Coinpayments possess great security features:

- BitGo services are integrated into this wallet to ensure a high level of security and to make transactions a lot faster.

- Safe - this feature is included with the purpose to protect user's money from thieves

- Multi-currency wallet - An ability to store different currencies in the same wallet

- Common - Often used in thousands of online stores for online purchasing

Exodus is another web-based digital wallet with remarkable design, reporting system and easy to use. When compared to other web wallets, the great thing about Exodus is that it has the similar features and maybe some better than others. Figure 3. shows Exodus interface wallet.

There are many features that this wallet gives but here is the list of the best security features:

- Multi-currency wallet - storing different cryptocurrencies in the same wallet along with other digital assets without additional fee

Figure 3:Exodus interface wallet

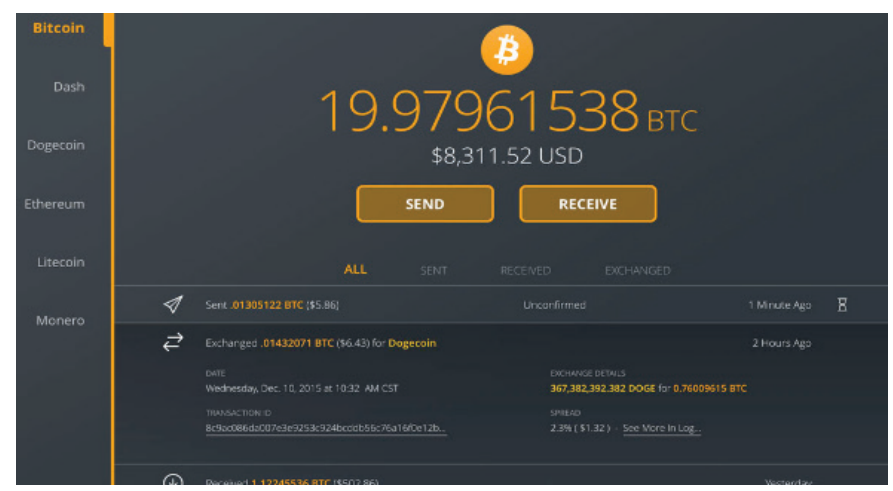

Source: https://www.exodus.io/\#

- Security - Even though this is an online wallet, at the same time is an offline wallet because when wallet is created the information are stored on the user's computer 
- Free registration - Everyone can fill out the form and become an owner of this type of crypto wallet

Jaxx is used as mobile and dekstop wallet. Todays' mobile wallets offer many security features in case the user loses his phone. In that case, they allow you to switch to another account. Features of Jaxx wallet are:

- Full control - When a private key is being created it's been stored at the user's computer, so even Jaxx company can't see the user's digital funds.

- $\quad$ Easily operated - Usually the online wallets demand a lot of steps to make the transaction. Jaxx model is based on Nada privacy model. This model protects confidentiality and privacy.

- Acceptable - Jaxx can be implemented on every major operating system

\section{Digital wallets security}

The crypto wallet as well as the real plastic wallet can be secured. In the case of the most popular cryptocurrency Bitcoin there are different data transfer functionalities. These things can be security issue but Bitcoin includes very high level of security which implies their proper use. When it comes to placing money on online platforms, attention should be focused on their security. In case of buying wallet for this cryptocurrency, it is recommended to use two-factor authentication. Smart way of storing money in the wallet can be compared with physical wallet. This means that the digital crypto wallet should contain a small amount of money for everyday use.

Backup wallet is just another expression for storing money on some other place or making a copy. Backup wallet can prevent problems that arise from a computer errors or data theft, but this request can be fulfilled if the data is encrypted. Data stored on the network are not one hundred percent secure. Any computer connected to the network can be affected by malicious software. An important safety practice is that data should be encrypted to avoid any chance to be compromised. It should be stored in several different locations. When it comes to different locations, it's not just about online storage but also on hardware devices such as USB, CD, external hard drive etc.

Encryption is very important for digital wallets. Encrypting digital wallet is one of the best ways to secure your funds which are stored inside the digital wallet. In this way, a password is set if someone tries to access the digital wallet. Password must not be lost because if that happens the funds will be lost. The difference between the cryptocurrency and the real money is that if the loss of password occurs, user can make a request to get a new password. In blockchain and cryptocurrency, full responsibility is placed on user. It is very important to create strong password which includes letters, characters, numbers.

Another way of storing and securing data is to use cold wallets. These wallets are hardware wallets which do not have connection to the internet. Offline transaction signing involves two computers sharing parts of the same digital wallet. The first computer should be disconnected from any network and only this computer contains a complete digital wallet and have an authorization to sign the transaction. The second computer has connection to the network and contains the digital wallet only for watching and can create unsigned transactions. The transaction can be done in a few steps: 
1. Create a new transaction on the computer that is connected to the network and store it on a USB drive.

2. Sign transaction with the computer that is not connected to the network.

3. Send the signed transaction with computer that is connected to the network.

The digital wallet software version should always be updated because every time when software is updated user will receive an important security updates. Updates can include some new features for digital wallet, it can prevent different problems various severity and many other things. Crypto wallets can use a multiple signature feature where multiple approvals are required for transaction to be spent. This type of protection can be used in bigger organizations such as banks where employees have access to its treasury. Web wallets also include multi signature feature. (Securing your wallet, 2018)

\section{Comparative analysis of traditional payment method vs cryptocurrencies}

We've conducted a rigorous comparative analysis between the traditional payment method and cryptocurrency method. According to this author, virtual currencies and mobile banking represent the greatest achievements in information technology so far. The advantage of these methods of payment is that they are easily accessible for each client and much faster than traditional payroll system. Along with this, the problem arises from the security aspects that can lead to identity theft. The solution for preventing identity theft of clients is the use of cryptography. In this way, decentralized networks have a high level of security. Compared to mobile banking, this system is much safer. Mobile banking does not provide PKI (public key infrastructure). The only way to verify authenticity on mobile phones is to get smart cards that have pre-installed symmetric keys. But this is not an anonymity solution that the decentralized systems have. (George F. Hurlburt)

In opinion of this author the biggest reason to use digital wallets and digital currencies is due to significantly reduced transaction fees. This method is much cheaper compared to traditional payment cards. Traditional pay system had freedom to increase commissions because they did not have competition to stop them. Apart from that, another reason for use of digital currencies is the guarantee of user's anonymity. The third reason for their use is that cryptocurrencies are protected from inflation.

On the other hand, because of the anonymity cryptocurrencies can be used for illegal purposes. Due to the large amount of money this kind of transactions would require a lot of high commissions if the client would use the traditional payment system or at some point it may come to account blocking. (Moore, The promise and perils of digital currencies, 2013)

Based on the research, there are various aspects of comparison between cryptocurrencies payment method and traditional payment method where some of them are given in the next table. 
Table 1:Positive and negative aspects

\begin{tabular}{|c|c|c|}
\hline Aspects & Traditional payment & Crypto payment \\
\hline Social acceptance & World-wide (+) & Limited (-) \\
\hline Authority & Central authority $(+/-)$ & Decentralized network $(+/-)$ \\
\hline Flexibility & Service provider (-) & Without service provider $(+)$ \\
\hline Payment processing & Necessary third party (-) & Direct payment between nodes $(+)$ \\
\hline Transaction speed & Couple of days (-) & Instantly transactions $(+)$ \\
\hline Transaction fee & Expensive charge fees (-) & Low or free transactions fees $(+)$ \\
\hline Refoundry & Changeful transaction $(+)$ & Permanent transaction (-(-) \\
\hline Anonymity & Client identified (-) & Alias authentication $(+)$ \\
\hline
\end{tabular}

The table 1 gives an overview of positive and negative aspects gained through the comparative analysis of traditional and crypto payment. Positive and negative aspects are shown in table columns indicating the advantages and disadvantage both payment systems.

Social acceptance: The traditional payment system is used everywhere in the world and it represents the standard. However, the crypto payment system is forbidden in some countries, which therefore limits its usability comparing to the traditional payment system.

Authority: The traditional payment method provides a certain level of security from their viewing angle, but on the other hand, this security in the centralized system is not $100 \%$ secure.

For the crypto payment, this is the huge improvement in the payment system because all nodes in the decentralized network have their own copies of all executed transactions in relation to the traditional payment system. A disadvantage of this system may be that there is no central authority in charge of saving the clients' money.

Flexibility: An advantage of the crypto payment method is the ability to send worldwide transactions at a given moment with very low fees while in the traditional payment system it takes much longer to execute the transaction.

Payment processing: There is no need for approving the transaction by a central authority and many other different restrictions for the crypto payment system.

Transaction speed: The benefit of using the crypto payment method is that the transactions are executed instantly.

Transaction fee: An advantage of using crypto payment method is that the transaction fees are very low or free of charge.

Irreversible: In crypto payment method, the client should think before executing the transaction because there is no way back once the transaction is executed.

Anonymity: Information about the clients or nodes are hidden in the crypto payment method. 


\section{Conclusion}

For the current year 2018 it is predicted that the use of digital wallets for cryptocurrencies will increase and that the use of physical wallets will be reduced. The most popular crypto currency, Bitcoin, reaches the highest record profits and slowly gets a reputation as legitimate currency. Based on the research so far it can be concluded that these wallets are very safe as well as suitable for use as the additional costs are minimal in relation to the costs when paying with physical money. Payment in cryptocurrencies provides these minimum costs because two nodes that execute a transaction operate directly where there is no inclusion of a third party. The only cost is payment to the network in which transaction is executed, for example Bitcoin network. Depending on the speed of transaction execution, there are different fees (in dollars per transaction) but they are much smaller than in traditional payment system.

\section{References}

Advantages and disadvantages of electronic payment systems. (n.d.). Retrieved from Unichange.me:https://unichange.me/articles/advantages_of_electronic_ payment_systems

Credit card cons and pros. (n.d.). Retrieved from Money super market: https://www. moneysupermarket.com/credit-cards/advantages-and-disadvantages/

Cryptocurrency Wallet Guide: A Step-By-Step Tutorial. (2018). Retrieved from Blockgeeks: https://blockgeeks.com/guides/cryptocurrency-wallet-guide/

Cryptocurrency wallets types. (n.d.). Retrieved from Hobo laptop: https:// hobowithalaptop.com/crypto-wallets

George, F., \& Hurlburt, I. B. (n.d.). Bitcoin: Benefit or Curse.

Hulburt, F. G., \& Bojanova, I. (2014). Bitcoin: Benefit or Curse. Semantic schoolar.

Moore, T. (2013). The promise and perils of digital currencies. International Journal of Critical Infrastructure Protection 6.

Moore, T. (n.d.). The promise and perils of digital currencies. Dallas, Texas: Computer Science and Engineering Department, Lyle School of Engineering, Southern Methodist University.

NXGEN. (n.d.). Retrieved from NXGEN: https://us.nxgen.com/advantages-anddisadvantages-of-different-payment-types/

Securing your wallet. (2018). Retrieved from Bitcoin: https://bitcoin.org/en/secureyour-wallet\#everyday

The difference between hot and cold wallets in the digital currency world. (n.d.). Retrieved from coti: https://medium.com/cotinetwork/the-difference-betweenhot-and-cold-wallets-in-the-digital-currency-world-1aa6f957ddd1

Veinović, M., \& Adamović, S. (2013). Kritpologija 1. Beograd: Univerzitet Singidunum. 